\title{
Pay-for-performance in disease management: a systematic review of the literature
}

\author{
Simone R de Bruin*, Caroline A Baan and Jeroen N Struijs
}

\begin{abstract}
Background: Pay-for-performance (P4P) is increasingly implemented in the healthcare system to encourage improvements in healthcare quality. P4P is a payment model that rewards healthcare providers for meeting preestablished targets for delivery of healthcare services by financial incentives. Based on their performance, healthcare providers receive either additional or reduced payment. Currently, little is known about P4P schemes intending to improve delivery of chronic care through disease management. The objectives of this paper are therefore to provide an overview of P4P schemes used to stimulate delivery of chronic care through disease management and to provide insight into their effects on healthcare quality and costs.
\end{abstract}

Methods: A systematic PubMed search was performed for English language papers published between 2000 and 2010 describing P4P schemes related to the implementation of disease management. Wagner's chronic care model was used to make disease management operational.

Results: Eight P4P schemes were identified, introduced in the USA $(n=6)$, Germany $(n=1)$, and Australia $(n=1)$. Five P4P schemes were part of a larger scheme of interventions to improve quality of care, whereas three P4P schemes were solely implemented. Most financial incentives were rewards, selective, and granted on the basis of absolute performance. More variation was found in incented entities and the basis for providing incentives. Information about motivation, certainty, size, frequency, and duration of the financial incentives was generally limited. Five studies were identified that evaluated the effects of P4P on healthcare quality. Most studies showed positive effects of P4P on healthcare quality. No studies were found that evaluated the effects of P4P on healthcare costs.

Conclusion: The number of P4P schemes to encourage disease management is limited. Hardly any information is available about the effects of such schemes on healthcare quality and costs.

\section{Background}

Chronic diseases are the leading cause of disability and death in the Western part of the world [1]. Over the coming years, the prevalence of chronic diseases is predicted to increase as a result of the rapid aging of the world population and the greater longevity of people with chronic conditions [2,3]. Healthcare systems struggle with coordinating care to people with chronic conditions. The healthcare system, traditionally predominated by a re-active approach and consisting of highly specialized echelons, needs to be transformed to realize patient-centered chronic care in which problems like

\footnotetext{
* Correspondence: simone.de.bruin@rivm.nl National Institute for Public Health and the Environment, Centre for Prevention and Health Services Research, P.O. Box 1, 3720 BA Bilthoven, The Netherlands
}

fragmentation, restricted self-management, and guideline non-adherence are limited $[4,5]$.

To deal with this challenge, policymakers and professionals introduced disease management programs (also referred to as e.g. case management, integrated care, managed care, and shared care) to enhance quality and continuity of care for the chronically ill. In broad terms disease management refers to a patient-centered approach of coordinated multiple healthcare interventions that aim to structure chronic care to a specific patient group $[4,6]$. A model that is perhaps best known from an international perspective, and that was used for this study to make disease management operational, is the Chronic Care Model (CCM) of Wagner et al. [5,7]. This model can be considered as a guide towards improving management and coordination of chronic conditions. The model suggests that disease management ideally comprises six interrelated 
components (i.e. health care organization, community resources, self-management support, decision support, delivery system design, and clinical information system) and that integration of these components is the key towards improving chronic care management [4].

It is generally believed that disease management programs result into improved patient health outcomes and into healthcare cost savings. There is, however, a lack of conclusive scientific evidence supporting these suggestions $[4,6,8,9]$. Nevertheless, interest in pay-for-performance (P4P) as a tool to stimulate delivery of chronic care through disease management is growing. P4P is a payment model that rewards healthcare providers for meeting preestablished targets for delivery of healthcare services by financial incentives [10]. Based on their performance, healthcare providers receive either additional or reduced payment. The reasoning behind P4P schemes is, by either rewarding or punishing healthcare providers for their performance, to improve quality of care [11,12]. P4P schemes, also known as e.g. performance based incentive programs and quality incentive payment systems, should not be confused with funding of disease management. Funding refers to recompensing delivery of healthcare services by healthcare providers via retrospective (e.g. fee-for-service or bundled payment) or prospective (e.g. capitation) payment contracts.

To date, little is known about the use of P4P schemes to stimulate delivery of chronic care through disease management and whether such schemes actually affect healthcare quality and healthcare costs. The objectives of the present paper are therefore (i) to provide an overview of P4P schemes that are currently used to stimulate delivery of chronic care through disease management and (ii) to gain insight into the effects of P4P on healthcare quality and healthcare costs.

\section{Methods}

\section{Study design and search strategy}

A systematic review of the literature was performed for insight into P4P schemes aiming at stimulation of delivery of chronic care through disease management. We conducted our search in PubMed focusing on English language papers published between January 2000 and January 2010. A comprehensive search strategy was developed by a librarian of our institute to identify studies matching the following search terms (Medical Subject Headings): case management, comprehensive health care, delivery of integrated health care, disease management, managed care programs, patient care management, patient-centered care, shared care, transmural care and variations of the keywords chronic disease, chronically ill, chronic illness, long term care and specified chronic conditions. These search terms were combined with variations of the following search terms: bundled payment, fee for services, health care reform, incentives, local partnerships, pay for performance, payment methods, practice based commissioning, physician incentive plans, prospective payment system, quality assurance, and reimbursement (mechanisms).

In addition to the electronic database search, relevant papers were identified through reference tracking and through a manual literature search on the internet. To obtain up-to-date information about the included P4P schemes, also websites of the P4P schemes and other relevant websites such as those of health insurers and Ministries of Health were consulted.

\section{Study selection}

Two reviewers (JS and SdB) independently reviewed the papers extracted by the search for their relevance by screening their title and abstract. If found relevant by both reviewers, the full-text paper was retrieved. Any disagreement between the reviewers was resolved by consensus. Papers describing P4P schemes focusing on the implementation of disease management programs were included.

In line with earlier studies $[9,13,14]$ also in this study the chronic care model (CCM) of Wagner et al. [5,7] was used to make disease management operational. The model suggests that disease management ideally comprises six interrelated components. Four components refer to the actual delivery of care by healthcare providers of a healthcare organization; 1. self-management support that helps patients and their families to obtain skills and confidence to manage their chronic condition (e.g. blood glucose monitoring) and assessment of problems and achievements on a regular basis; 2. delivery system design; focus on coordinated multidisciplinary collaboration between caregivers (i.e. multidisciplinary team, individual care plans); 3. decision support; evidence-based guidelines providing clinical standards for high-quality chronic care, and 4. development of clinical information systems; supplying care teams with feedback, reminding them to comply with practice guidelines and providing registries for planning individual and population-based care $[7,15]$. The two remaining components mainly refer to the context where chronic care is provided: 5 . the healthcare system which encompasses the aforementioned elements, refers to the organizational context where chronic care is provided. A healthcare system seeking to improve chronic care must be motivated and prepared for change throughout the organization. Leadership must identify care improvement as important work, and translate it into clear improvement goals and policies that are addressed through application of effective improvement strategies and 6. links towards community resources and policies. The healthcare system is embedded in a community that includes organizations/programs that may support or expand a healthcare system's care for chronically 
ill patients (e.g. physical activity programs delivered by a local fitness centre). In our study, the term disease management was used for programs that included interventions that could be related to two or more components of the CCM.

\section{Data extraction}

P4P schemes identified by the literature search were described on the basis of the nine dimensions of P4P schemes defined by Conrad and Perry [10] (Table 1). This classification was used to systematically disentangle the P4P schemes. We additionally reported the country where the scheme was introduced, the CCM elements to which the scheme could be related, and the goal of each scheme (Table 2). Of the papers reporting studies that evaluated the effects of P4P on quality of healthcare and healthcare costs we described the characteristics of the evaluation study (e.g. design, sample size, years of data collection), outcome measures, and study outcomes (Table 3).

\section{Results}

\section{Paper retrieval}

Our literature search yielded 147 potentially relevant papers. On the basis of their title and abstract, 52 papers were selected to be retrieved full-text for in-depth screening. This screening process resulted into 12 papers eligible for our review. Reasons for exclusion are given in Figure 1. Additionally, six papers were identified through reference tracking and through a manual literature search on the internet. Hence, 18 papers were included in our review. The 18 papers described eight different P4P schemes that intend to improve chronic care delivery through disease management (Table 2). Some papers described the same P4P scheme which helped us to retrieve the fullest possible information about the different characteristics of the P4P schemes.

\section{Characteristics pay-for-performance schemes General characteristics}

Table 2 presents the characteristics of the eight included P4P schemes. Six P4P schemes were introduced in the USA: 1. the Western New York Physician Incentive Project (WNY-PIP) [16]; 2. Performance Based Incentive Program of Highmark Blue Cross Blue Shield (PBIP) [12,17]; 3. Partners Community Healthcare Inc./Brigham and Women's Hospital Physicians Organization pay-forperformance program (BWPO-P4P) $[18,19]$; 4. Bridges to Excellence Program (BTE) [12,20-23]; 5. Integrated Healthcare Association pay-for-performance program (IHA-P4P) [24-31]; and 6. the Medicare Physician Group Practice Demonstration (MPGPD) [32,33]. One P4P scheme was introduced in Germany: 7. Scheme to stimulate sickness funds to enroll patients in German

Table 1 Features of P4P schemes and their dimensions

\begin{tabular}{|c|c|}
\hline Feature & Dimensions \\
\hline 1. Type & $\begin{array}{l}\text { - Reward: incentive implies increase in payments } \\
\text { - Penalty: incentive implies decrease in payments }\end{array}$ \\
\hline 2. Nature incented entity & $\begin{array}{l}\text { - Individual: incentive is granted to an individual (e.g. healthcare provider such as GP) } \\
\text { - Group: incentive is granted to a group (e.g. clinical team, GP practice, hospital trust) }\end{array}$ \\
\hline $\begin{array}{l}\text { 3. Focal quality behavior targeted } \\
\text { by incentive }\end{array}$ & $\begin{array}{l}\text { - Structure: incentives are based on resources assembled to deliver care (including personnel, facilities, IT, and } \\
\text { materials) } \\
\text { - Process: incentives are based on the completion of specific tasks or recommended treatments (e.g. } \\
\text { performance measures, clinical quality) } \\
\text { - Outcome: incentives are based on ultimate results of care (e.g. patient experience, health status, morbidity, } \\
\text { and mortality) }\end{array}$ \\
\hline 4. Scope & $\begin{array}{l}\text { - General: incentives target at general domain of quality (e.g. payment for each patient enrolled in disease } \\
\text { management program). } \\
\text { - Selective: incentives target a specific domain of quality (e.g. periodic blood pressure readings or cholesterol } \\
\text { screening) }\end{array}$ \\
\hline 5. Motivation & $\begin{array}{l}\text { - Intrinsic: incentive affects intrinsic motivation to deliver high quality care (e.g. patient benefit) } \\
\text { • Extrinsic: incentive affects extrinsic motivation to deliver high quality care (e.g. economic interest) }\end{array}$ \\
\hline 6. Scale & $\begin{array}{l}\text { - Relative: incentive is paid for achieving a given comparative ranking among providers (e.g. hospitals in top } 2 \\
\text { performing quartiles are offered increases in tariff payments) } \\
\text { - Absolute: incentives is paid for a continuous gradient of quality improvement (e.g. sickness funds receive } \\
\text { higher payments for each patient enrolled in disease management program) }\end{array}$ \\
\hline 7. Size & - Amount of money provided or withdrawn \\
\hline 8. Certainty & $\begin{array}{l}\text { - Certain: incented entity is certain about achievability of targets (e.g. targets seem easily achievable; } \\
\text { guaranteed reward schedule) } \\
\text { - Uncertain: incented entity is uncertain about achievability of targets (e.g. targets seem not easily achievable; } \\
\text { competition for limited funds) }\end{array}$ \\
\hline 9. Frequency and duration & $\begin{array}{l}\text { - Frequency: number of times a year an incentive is provided } \\
\text { - Duration: number of years an incentive is provided }\end{array}$ \\
\hline
\end{tabular}


Table 2 General characteristics pay-for-performance schemes

\begin{tabular}{|c|c|c|c|c|c|c|c|c|c|c|c|c|}
\hline $\begin{array}{l}\text { Pay-for- } \\
\text { performance } \\
\text { scheme }\end{array}$ & Country & $\begin{array}{l}\text { Elements chronic care } \\
\text { model }\end{array}$ & $\begin{array}{l}\text { Goal and patient } \\
\text { population }\end{array}$ & Type & Incented entity & $\begin{array}{l}\text { Focal quality } \\
\text { behavior }\end{array}$ & Scope & Motivation & Scale & Size & Certainty & $\begin{array}{l}\text { Frequency } \\
\text { and duration }\end{array}$ \\
\hline \multicolumn{13}{|c|}{ Schemes in which financial incentives are granted to healthcare providers for delivering chronic care through disease management } \\
\hline $\begin{array}{l}\text { Western New } \\
\text { York Physician } \\
\text { Incentive } \\
\text { Program (WNY- } \\
\text { PIP) [16] }\end{array}$ & USA & $\begin{array}{l}\text { P4P simultaneously } \\
\text { implemented with: } \\
\text { 1. change in delivery system } \\
\text { design (establishment of } \\
\text { new routines in physician's } \\
\text { office) } \\
\text { 2. decision support (e.g. } \\
\text { assessment tools, educating } \\
\text { and training physician office } \\
\text { staff, reflective information } \\
\text { feedback ) } \\
\text { 3. self-management support } \\
\text { (e.g. providing patient } \\
\text { education materials) }\end{array}$ & $\begin{array}{l}\text { 1. To improve } \\
\text { chronic care } \\
\text { treatment for } \\
\text { diabetes patients } \\
\text { 2. To explore } \\
\text { effectiveness of } \\
\text { financial incentives } \\
\text { in improving care } \\
\text { for this patient } \\
\text { population } \\
\text { 3. To promote new } \\
\text { routines in } \\
\text { physician's office } \\
\text { Ultimate goal: } \\
\text { improve patient } \\
\text { health }\end{array}$ & Reward & $\begin{array}{l}\text { Individual: } \\
\text { Physician }\end{array}$ & $\begin{array}{l}\text { Process: } \\
6 \text { clinical Ql based } \\
\text { on ADA clinical } \\
\text { guideline Outcome: } \\
3 \text { patient outcome } \\
\text { indicators }\end{array}$ & $\begin{array}{l}\text { Selective: health } \\
\text { plans pay financial } \\
\text { incentives based } \\
\text { on composite } \\
\text { score on process } \\
\text { and outcome } \\
\text { indicators }\end{array}$ & N.A. & $\begin{array}{l}\text { Absolute } \\
\text { 1. scoring above } \\
\text { predetermined } \\
\text { target on composite } \\
\text { score based on } \\
\text { performance on } \\
\text { process and } \\
\text { outcome indicators } \\
2.50 \% \text { improvement } \\
\text { in composite score }\end{array}$ & $\begin{array}{l}\text { Size of reward } \\
\text { depends on } \\
\text { weighted composite } \\
\text { score. } \\
\text { Actual payments } \\
\text { varied from } \$ 3,000 \\
\text { till } \$ 12,000(2003)\end{array}$ & $\begin{array}{l}13 \text { of } 21 \text { physician } \\
\text { earned a financial } \\
\text { reward. }\end{array}$ & Annually \\
\hline $\begin{array}{l}\text { Performance } \\
\text { Based Incentive } \\
\text { Program (PBIP) } \\
\text { Highmark Blue } \\
\text { Cross Blue } \\
\text { Shield [12,17] }\end{array}$ & USA & $\begin{array}{l}\text { P4P simultaneously } \\
\text { implemented with: } \\
\text { 1. decision support (e.g. up } \\
\text { to date clinical physician } \\
\text { guidelines, reflective } \\
\text { information feedback, regular } \\
\text { review by medical } \\
\text { management consultant) } \\
\text { 2. clinical information system } \\
\text { (e.g. sharing practice specific } \\
\text { data with other physicians } \\
\text { for benchmarking) }\end{array}$ & $\begin{array}{l}\text { Encourage } \\
\text { healthcare providers } \\
\text { to deliver best } \\
\text { possible quality care } \\
\text { and encourage } \\
\text { coordinated care } \\
\text { (patient population } \\
\text { unknown) }\end{array}$ & Reward & $\begin{array}{l}\text { Group: physician } \\
\text { groups (not } \\
\text { further specified) }\end{array}$ & $\begin{array}{l}\text { Structure: electronic } \\
\text { connectivity, } \\
\text { Process: clinical } \\
\text { quality } \\
\text { Outcome: patient } \\
\text { satisfaction }\end{array}$ & N.A. & N.A. & $\begin{array}{l}\text { Relative: physician } \\
\text { groups are rewarded } \\
\text { if they exceed other } \\
\text { physicians (in and } \\
\text { out of the program) } \\
\text { in performance on } \\
\text { structure, process, } \\
\text { and outcome } \\
\text { indicators }\end{array}$ & N.A. & N.A. & N.A. \\
\hline $\begin{array}{l}\text { Partners } \\
\text { Community } \\
\text { Healthcare Inc./ } \\
\text { Brigham and } \\
\text { Women's } \\
\text { Physicians } \\
\text { Organization } \\
\text { pay-for- } \\
\text { performance } \\
\text { program (BWPO- } \\
\text { PAP) [18,19] }\end{array}$ & USA & $\begin{array}{l}\text { P4P simultaneously } \\
\text { implemented with: } \\
\text { 1. decision support (e.g. non- } \\
\text { physician staff contact } \\
\text { patients and physicians to } \\
\text { improve compliance with } \\
\text { practice guidelines) } \\
\text { 2. change in delivery system } \\
\text { design (e.g. central diabetes } \\
\text { patient outreach coordinator } \\
\text { tracking data and } \\
\text { performance progress and } \\
\text { checking compliance of } \\
\text { patients; home visits) } \\
\text { 3. clinical information system } \\
\text { (adoption of electronic } \\
\text { medical records and claims } \\
\text { that track patient screening } \\
\text { data (HEDIS) for e.g. } \\
\text { benchmarking; central office } \\
\text { sending reminder letters). }\end{array}$ & $\begin{array}{l}\text { Improve quality and } \\
\text { efficiency of care } \\
\text { within the } \\
\text { organization with } \\
\text { regard to inpatient } \\
\text { admissions, } \\
\text { radiology, diabetes } \\
\text { care, and asthma } \\
\text { care. } \\
\text { Only P4P scheme for } \\
\text { diabetes and asthma } \\
\text { care are relevant for } \\
\text { our review. }\end{array}$ & $\begin{array}{l}\text { Penalty: } \\
\text { programs } \\
\text { operate by } \\
\text { withholding } \\
10 \% \text { of } \\
\text { physician/ } \\
\text { hospital fees } \\
\text { and } \\
\text { returning } \\
\text { those fees } \\
\text { based on } \\
\text { whether } \\
\text { quality and } \\
\text { efficiency } \\
\text { targets are } \\
\text { achieved }\end{array}$ & $\begin{array}{l}\text { Group: network of } \\
\text { primary care } \\
\text { physicians, } \\
\text { ophthalmologists, } \\
\text { and staff }\end{array}$ & $\begin{array}{l}\text { Process: clinical } \\
\text { quality according to } \\
\text { HEDIS measures } \\
\text { Outcome: achieving } \\
\text { target outcomes } \\
\text { Shiff from } \\
\text { performance targets } \\
\text { that focus on } \\
\text { process indicators to } \\
\text { targets that focus on } \\
\text { outcome indicators }\end{array}$ & $\begin{array}{l}\text { Selective: } \\
\text { incentives based } \\
\text { on performance } \\
\text { on process and } \\
\text { outcome } \\
\text { indicators. }\end{array}$ & N.A. & $\begin{array}{l}\text { Relative, withhold is } \\
\text { returned if network: } \\
\text { 1. scores above state } \\
\text { or national } 90^{\text {th }} \\
\text { percentile of HEDIS } \\
\text { targets } \\
\text { 2. improves baseline } \\
\text { performance Some } \\
\text { regional service } \\
\text { organizations } \\
\text { provide additional } \\
\text { incentives directly to } \\
\text { physicians whose } \\
\text { patients meet HEDIS } \\
\text { targets and many } \\
\text { regional service } \\
\text { organizations } \\
\text { provide bonuses for } \\
\text { non-clinical staff } \\
\text { members who are } \\
\text { critical to success of } \\
\text { these programs }\end{array}$ & $\begin{array}{l}\text { Portion of } \\
\text { withholding that will } \\
\text { be returned } \\
\text { depends on } \\
\text { performance on } \\
\text { HEDIS measure (in } \\
\text { 2006: moderate- } \\
\text { volume primary care } \\
\text { physician practices } \\
\text { could earn } \\
\text { additional } \$ 3000 \text { to } \\
\$ 5000 \text { per physician } \\
\text { if network met P4P } \\
\text { HEDIS targets) }\end{array}$ & N.A. & Annually \\
\hline
\end{tabular}


Table 2 General characteristics pay-for-performance schemes (Continued)

\begin{tabular}{|c|c|c|c|c|c|c|c|c|c|c|c|c|}
\hline $\begin{array}{l}\text { Bridges to } \\
\text { Excellence } \\
\text { program (BTE) } \\
{[12,20-23]}\end{array}$ & USA & $\begin{array}{l}\text { P4P to stimulate } \\
\text { implementation of: } \\
\text { 1. self-management support } \\
\text { (e.g. patient education, } \\
\text { shared decision-making) } \\
\text { 2. decision support (e.g. } \\
\text { clinical standards set by } \\
\text { NCQA/ADA) } \\
\text { 3. clinical information system } \\
\text { (e.g. adoption of electronic } \\
\text { systems to maintain medical } \\
\text { records documenting care } \\
\text { delivery for reflective } \\
\text { information feedback } \\
\text { benchmarking) }\end{array}$ & $\begin{array}{l}\text { Create significant } \\
\text { improvements in } \\
\text { quality of asthma } \\
\text { care, cardiac care, } \\
\text { congestive heart } \\
\text { failure care, coronary } \\
\text { artery disease care, } \\
\text { depression care, } \\
\text { diabetes care, } \\
\text { hypertension care, } \\
\text { and spine care by } \\
\text { recognizing and } \\
\text { rewarding health } \\
\text { care providers for } \\
\text { implementing } \\
\text { elements of CCM } \\
\text { and delivering safe, } \\
\text { timely, effective, } \\
\text { efficient, equitable, } \\
\text { and patient-centered } \\
\text { care }\end{array}$ & $\begin{array}{l}\text { Reward: } \\
\text { higher } \\
\text { revenue }\end{array}$ & $\begin{array}{l}\text { Individual: } \\
\text { physicians, nurse } \\
\text { practitioners, and } \\
\text { physician } \\
\text { assistants certified } \\
\text { through provider } \\
\text { recognition } \\
\text { program of NCQA }\end{array}$ & $\begin{array}{l}\text { Structure: clinicians } \\
\text { should comply with } \\
\text { standards for clinical } \\
\text { information systems } \\
\text { Process: clinicians } \\
\text { should comply with } \\
\text { national standards } \\
\text { for clinical care } \\
\text { management, } \\
\text { patient education } \\
\text { and support }\end{array}$ & $\begin{array}{l}\text { Selective: incentive } \\
\text { based on whether } \\
\text { healthcare } \\
\text { providers meet a } \\
\text { set of structure } \\
\text { and process } \\
\text { measures, which } \\
\text { are scored to } \\
\text { create overall } \\
\text { program score } \\
\text { where } 60 \text { is most } \\
\text { often the passing } \\
\text { grade. }\end{array}$ & N.A. & $\begin{array}{l}\text { Absolute: incentive is } \\
\text { provided when } \\
\text { healthcare } \\
\text { professionals meet } \\
\text { certain performance } \\
\text { measures. } \\
\text { Each measure has } \\
\text { an assigned } \\
\text { maximum available } \\
\text { point value. } \\
\text { Clinicians achieve } \\
\text { points for a measure } \\
\text { based on the \% of } \\
\text { patient sample that } \\
\text { meets or exceeds } \\
\text { the set thresholds } \\
\text { for that measure. }\end{array}$ & $\begin{array}{l}\text { Depends on level of } \\
\text { performance. Size of } \\
\text { rewards changes } \\
\text { over time and differs } \\
\text { between health } \\
\text { plans that participate } \\
\text { in Bridges to } \\
\text { Excellence. }\end{array}$ & N.A. & Annually \\
\hline $\begin{array}{l}\text { Integrated } \\
\text { Healthcare } \\
\text { Association Pay- } \\
\text { for-performance } \\
\text { Program (IHA- } \\
\text { P4P) [24-29,31] }\end{array}$ & USA & $\begin{array}{l}\text { P4P to stimulate } \\
\text { implementation of: } \\
\text { 1. change in delivery system } \\
\text { design (e.g. redesigning } \\
\text { processes and creating a } \\
\text { systematic approach to } \\
\text { diabetes care such as } \\
\text { registries, actionable reports, } \\
\text { and care management } \\
\text { processes) } \\
\text { 2. decision support (using } \\
\text { evidence-based national } \\
\text { measures) } \\
\text { 3. clinical information system } \\
\text { (e.g. adoption infrastructure } \\
\text { for systematic processes of } \\
\text { care; electronic medical } \\
\text { records, reminder systems, } \\
\text { reflective information } \\
\text { feedback, benchmarking). }\end{array}$ & $\begin{array}{l}\text { Stimulate provider } \\
\text { organizations to } \\
\text { consistently } \\
\text { demonstrate high } \\
\text { levels of quality } \\
\text { performance with } \\
\text { regard to preventive } \\
\text { care, treatment of } \\
\text { acute conditions, } \\
\text { and treatment of } \\
\text { chronic conditions } \\
\text { (asthma, diabetes, } \\
\text { and coronary heart } \\
\text { disease) through } \\
\text { public recognition } \\
\text { and financial reward } \\
\text { Only financial } \\
\text { incentives for } \\
\text { chronic conditions } \\
\text { are relevant for our } \\
\text { review. }\end{array}$ & $\begin{array}{l}\text { Reward: } \\
\text { provider } \\
\text { groups earn } \\
\text { financial } \\
\text { rewards if } \\
\text { they } \\
\text { participate } \\
\text { in the } \\
\text { program } \\
\text { and perform } \\
\text { well on } \\
\text { selected } \\
\text { measures }\end{array}$ & $\begin{array}{l}\text { Group: physician } \\
\text { groups }\end{array}$ & $\begin{array}{l}\text { Structure: adoption } \\
\text { of IT enabled system } \\
\text { to support patient } \\
\text { care } \\
\text { Process: } 1 \text {. clinical } \\
\text { quality: preventive } \\
\text { screening, treatment } \\
\text { of asthma, diabetes, } \\
\text { and coronary artery } \\
\text { disease; } 2 \text {. } \\
\text { coordinated diabetes } \\
\text { care } \\
\text { Outcome: patient } \\
\text { experience } \\
\text { Measure set is } \\
\text { dynamic with new } \\
\text { measures added } \\
\text { each year. }\end{array}$ & $\begin{array}{l}\text { Selective: health } \\
\text { plans pay financial } \\
\text { incentives based } \\
\text { on composite } \\
\text { score on } \\
\text { established } \\
\text { structure, process, } \\
\text { and outcome } \\
\text { measures. } \\
\text { Composite score is } \\
\text { calculated and } \\
\text { then weighted: } \\
\text { clinical quality } \\
55 \% \text {, patient } \\
\text { experience } 25 \%, \\
\text { coordinated } \\
\text { diabetes registry } \\
5 \%, \text { IT enabled } \\
\text { systemness } 15 \%, \\
\text { resulting in overall } \\
\text { performance score }\end{array}$ & N.A. & $\begin{array}{l}\text { Absolute: } \\
\text { Physician groups } \\
\text { may receive } \\
\text { incentive } \\
\text { incremental financial } \\
\text { payment for scoring } \\
\text { in any of the } \\
\text { category measures } \\
\text { as long as the group } \\
\text { scores in the } \\
\text { appropriate } \\
\text { percentile ranking as } \\
\text { determined by the } \\
\text { health plan. }\end{array}$ & $\begin{array}{l}\text { Each health plan } \\
\text { that participates in } \\
\text { IHA-P4P scheme } \\
\text { determines its own } \\
\text { budget and } \\
\text { methodology for } \\
\text { calculating and } \\
\text { distributing } \\
\text { payments to } \\
\text { physician groups. On } \\
\text { average about } 1 \% \text { of } \\
\text { base income of } \\
\text { physician group (in } \\
\text { 2009). }\end{array}$ & N.A. & Annually \\
\hline
\end{tabular}


Table 2 General characteristics pay-for-performance schemes (Continued)

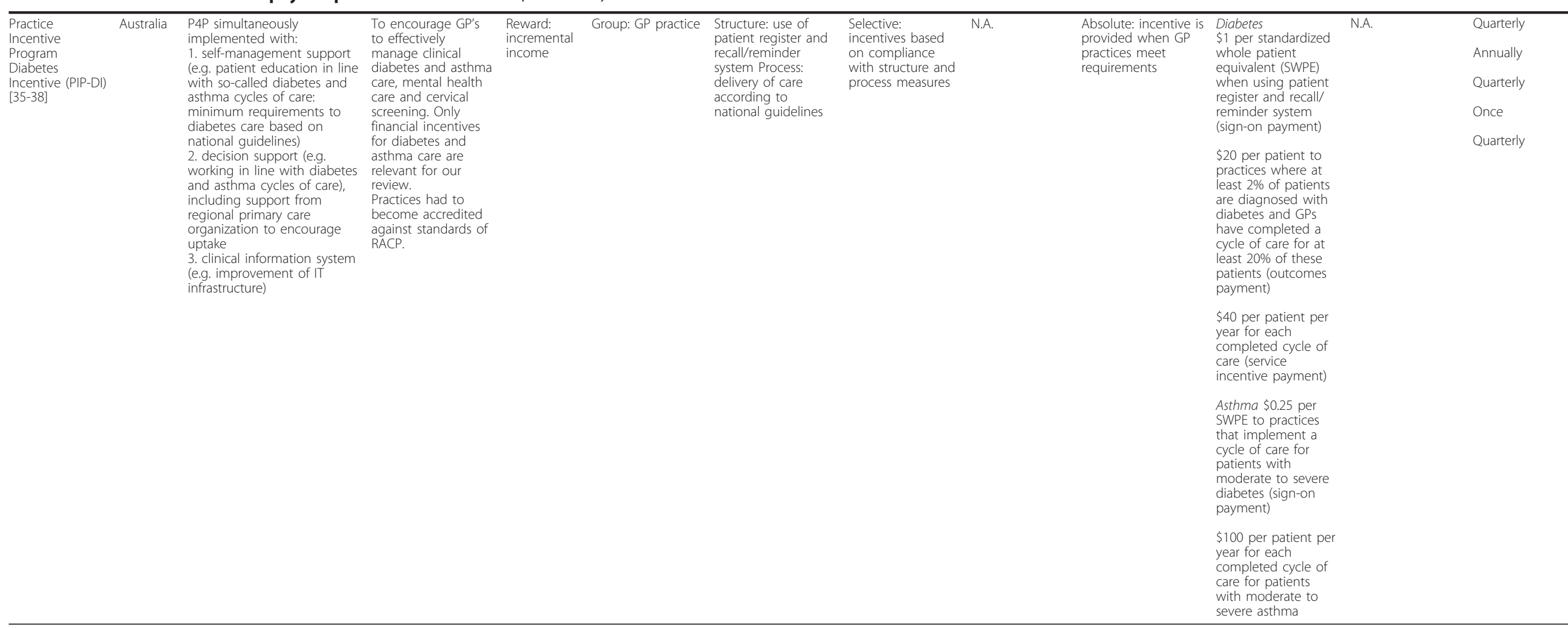


Table 2 General characteristics pay-for-performance schemes (Continued)

\begin{tabular}{|c|c|c|c|c|c|c|c|}
\hline $\begin{array}{l}\text { Medicare } \\
\text { Physician Group } \\
\text { Practice } \\
\text { Demonstration } \\
\text { (MPGPD) [32,33] }\end{array}$ & USA & $\begin{array}{l}\text { P4P simultaneously } \\
\text { implemented with: } \\
\text { 1. self-management support } \\
\text { (e.g. patient education, active } \\
\text { communication of patients } \\
\text { with physicians and nurses, } \\
\text { maintaining diet and exercise } \\
\text { programs) } \\
\text { 2. change in delivery system } \\
\text { design (e.g. delegating tasks } \\
\text { of physicians to non- } \\
\text { physicians) } \\
\text { 3. clinical information } \\
\text { systems (e.g. electronic } \\
\text { medical records, patient } \\
\text { monitoring systems) }\end{array}$ & $\begin{array}{l}\text { Quality improvement } \\
\text { and cost efficiency } \\
\text { of diabetes care, } \\
\text { heart failure care, } \\
\text { cardiac care, and } \\
\text { preventive care at } \\
\text { the level of the PGP }\end{array}$ & Reward & Group: PGP & $\begin{array}{l}\text { Process: clinical } \\
\text { quality according to } \\
\text { HEDIS measures } \\
\text { Outcome: clinical } \\
\text { quality according to } \\
\text { HEDIS measures } \\
32 \text { isdicators are } \\
\text { subset of CMS } \\
\text { Quality } \\
\text { Measurement and } \\
\text { Health assessment } \\
\text { Group for the } \\
\text { Doctors Office } \\
\text { Quality and } \\
\text { comprise both } \\
\text { process and } \\
\text { outcome indicators. }\end{array}$ & $\begin{array}{l}\text { Selective: } \\
\text { Incentives based } \\
\text { on performance } \\
\text { on broad range of } \\
\text { quality indicators } \\
\text { which focused on } \\
\text { diabetes mellitus, } \\
\text { heart failure, } \\
\text { coronary artery } \\
\text { disease and } \\
\text { hypertension, and } \\
\text { preventive care. }\end{array}$ \\
\hline
\end{tabular}

\begin{tabular}{|c|c|c|c|}
\hline $\begin{array}{l}\text { Absolute and } \\
\text { elative Absolute: if } \\
\text { cost saving } \geq 2 \% \text { of } \\
\text { arget expenditures } \\
\text { then } 20 \% \text { directly to } \\
\text { Medicare and } 80 \% \\
\text { to PGP. The portion } \\
\text { orovided to PGP is } \\
\text { divided in cost } \\
\text { oerformance } \\
\text { aayment (fixed } \\
\text { oayment) and } \\
\text { quality performance } \\
\text { oayment. } \\
\text { Quality performance } \\
\text { aayment is based on } \\
\text { absolute and/or } \\
\text { elative performance. } \\
\text { To earn payment, } \\
\text { FGP must achieve } \\
\text { for each indicator at } \\
\text { east } 1 \text { of } 3 \text { targets: } \\
\text { 1. achieve } \geq 75 \% \\
\text { compliance or HEDIS } \\
\text { mean for the } \\
\text { measure (absolute); } \\
\text { 2. achieve } 70^{\text {th }} \\
\text { bercentile Medicare } \\
\text { evel (relative); } 3 \text {. } \\
\text { demonstrate } \geq 10 \% \\
\text { mprovement in } \\
\text { compliance } \\
\text { absolute) }\end{array}$ & $\begin{array}{l}\text { A shared savings } \\
\text { provider payment } \\
\text { model in which } \\
\text { savings are shared } \\
\text { between } \\
\text { participating } \\
\text { physician groups } \\
\text { and the Medicare } \\
\text { groups. A higher } \\
\text { portion of the saving } \\
\text { can be retained by } \\
\text { PGP by good } \\
\text { performance on } \\
\text { indicators. } \\
\text { Size depends on } \\
\text { score on quality } \\
\text { indicators. In total } 2 \\
\text { PGPs received } \\
\text { performance } \\
\text { payments of in total } \\
\$ 7.3 \text { million as their } \\
\text { share in the total } \\
\text { saving of } \$ 9.5 \\
\text { million. }\end{array}$ & $\begin{array}{l}2 \text { of } 10 \text { PGP } \\
\text { earned a reward. }\end{array}$ & Annually \\
\hline
\end{tabular}

\section{Schemes in which financial incentives are granted to health insurers to enroll patients in disease management programs}

\begin{tabular}{|c|c|c|c|c|c|c|c|c|c|c|c|c|}
\hline $\begin{array}{l}\text { Incentive to } \\
\text { stimulate } \\
\text { sickness funds } \\
\text { to enroll } \\
\text { patients in } \\
\text { disease } \\
\text { management } \\
\text { program (DMP- } \\
\text { P4P) [34] }\end{array}$ & Germany & $\begin{array}{l}\text { P4P to stimulate } \\
\text { implementation of certified } \\
\text { DMPs. } \\
\text { Information about when } \\
\text { DMPs are classified as } \\
\text { "certified" is limited. } \\
\text { However, the following CCM } \\
\text { elements are considered as } \\
\text { important components of } \\
\text { DMPs: } \\
\text { 1. self-management support } \\
\text { (e.g. patient education) } \\
\text { 2. clinical information } \\
\text { systems (e.g. quality } \\
\text { management systems, } \\
\text { feedback systems) }\end{array}$ & $\begin{array}{l}\text { Stimulate sickness } \\
\text { funds to enroll } \\
\text { chronically ill } \\
\text { patients (diabetes } \\
\text { type } 1 \text { and } 2 \text {, } \\
\text { coronary heart } \\
\text { disease, breast } \\
\text { cancer, asthma, and } \\
\text { COPD) in DMPs } \\
\text { which are expected } \\
\text { to improve quality } \\
\text { and cost- } \\
\text { effectiveness of } \\
\text { healthcare for } \\
\text { patients with chronic } \\
\text { conditions }\end{array}$ & $\begin{array}{l}\text { Reward: } \\
\text { sickness } \\
\text { funds that } \\
\text { set op } \\
\text { DMPs are } \\
\text { rewarded } \\
\text { with } \\
\text { additional } \\
\text { payments } \\
\text { from risk } \\
\text { adjustment } \\
\text { scheme }\end{array}$ & $\begin{array}{l}\text { Group: sickness } \\
\text { funds }\end{array}$ & $\begin{array}{l}\text { Structure: setting-up } \\
\text { certified disease } \\
\text { management } \\
\text { program }\end{array}$ & $\begin{array}{l}\text { General: if sickness } \\
\text { funds set up } \\
\text { certified DMPs and } \\
\text { are able to enroll } \\
\text { a high number of } \\
\text { chronically ill } \\
\text { patients for the } \\
\text { relevant disease, } \\
\text { they receive } \\
\text { additional } \\
\text { payments from } \\
\text { risk adjustment } \\
\text { scheme. } \\
\text { If sickness funds } \\
\text { do not set up } \\
\text { DMPs or if they } \\
\text { are able to do so } \\
\text { but are not able } \\
\text { to enroll a high } \\
\text { number of } \\
\text { chronically ill } \\
\text { patients, they will } \\
\text { receive fewer } \\
\text { payments from } \\
\text { the risk } \\
\text { adjustment } \\
\text { scheme }\end{array}$ & N.A. & $\begin{array}{l}\text { Absolute: sickness } \\
\text { funds receive higher } \\
\text { payments for } \\
\text { patients enrolled in } \\
\text { certified DMP }\end{array}$ & $\begin{array}{l}\text { Payments from risk } \\
\text { adjustment system. } \\
\text { Size unknown. }\end{array}$ & N.A. & N.A. \\
\hline
\end{tabular}

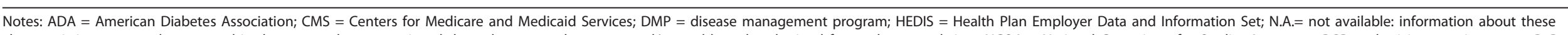

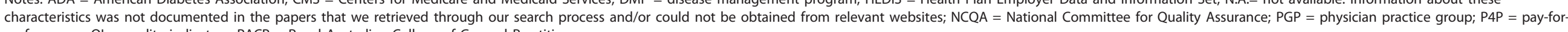
performance; $\mathrm{QI}=$ quality indicators; RACP = Royal Australian College of General Practitioners. 
Table 3 Effects pay-for-performance on healthcare quality

\begin{tabular}{|c|c|c|c|c|}
\hline Incentive & Study design (N) & $\begin{array}{l}\text { Year(s) } \\
\text { data } \\
\text { collection }\end{array}$ & Relevant outcome measures & Healthcare quality \\
\hline $\begin{array}{l}\text { Western New York } \\
\text { Physician Incentive } \\
\text { Program (WNY- } \\
\text { P4P) [16] }\end{array}$ & $\begin{array}{l}\text { Pre-post test } \\
\text { Experimental group: patients }(n= \\
624) \text { whose physicians }(n=21) \\
\text { participated in P4P scheme } \\
\text { Control group: sample of diabetic } \\
\text { patients from health plan }\end{array}$ & $2002-2003$ & $\begin{array}{l}\text { - Quality of care based on a } \\
\text { composite score which was based } \\
\text { on process and outcome measures. }\end{array}$ & $\begin{array}{l}\text { - Average of physician's composite } \\
\text { scores increased } 48 \% \text { (baseline to } \\
\text { end of project). } \\
\text { - } 13 \text { out of } 21 \text { physicians improved } \\
\text { their average composite score } \\
\text { enough to earn some level of } \\
\text { financial reward. } \\
\text { - Of the } 8 \text { physicians not receiving } \\
\text { reward, } 6 \text { improved their composite } \\
\text { score. }\end{array}$ \\
\hline $\begin{array}{l}\text { Integrated } \\
\text { Healthcare } \\
\text { Association Pay-for- } \\
\text { performance } \\
\text { Program (IHA-P4P) } \\
\text { [30] }\end{array}$ & $\begin{array}{l}\text { Cross-sectional analysis of linked } \\
2006 \text { clinical performance scores } \\
\text { from IHA-P4P and survey data from } \\
\text { the } 2^{\text {nd }} \text { National Study of Physician } \\
\text { Organizations among } 108 \text { California } \\
\text { physician organizations. }\end{array}$ & 2006 & $\begin{array}{l}\text { - Association between clinical } \\
\text { performance and the use of chronic } \\
\text { management processes } \\
\text { - Association between clinical } \\
\text { performance and electronic medical } \\
\text { record capabilities } \\
\text { - Association between clinical } \\
\text { performance and participation in } \\
\text { external quality improvement } \\
\text { initiatives. }\end{array}$ & $\begin{array}{l}\text { - Physician organizations investing } \\
\text { more heavily in care management } \\
\text { processes (e.g. patient registries, } \\
\text { physician reminders and feedback, } \\
\text { patient reminders and education) } \\
\text { may achieve better performance } \\
\text { scores. } \\
\text { - Use of organized quality } \\
\text { improvement efforts (e.g. } \\
\text { participation in QI program) may be } \\
\text { associated with increased delivery of } \\
\text { recommended care processes, which } \\
\text { in the context of the study } \\
\text { translated into better performance } \\
\text { on the clinical measures that were } \\
\text { rewarded in the P4P scheme. }\end{array}$ \\
\hline
\end{tabular}

\begin{tabular}{|c|c|c|c|c|}
\hline $\begin{array}{l}\text { Practice Incentive } \\
\text { Program Diabetes } \\
\text { Incentive (PIP-DI) } \\
\text { [38] }\end{array}$ & $\begin{array}{l}\text { Retrospective study based on dataset } \\
\text { from BEACH study (data from } 100 \\
\text { consecutive encounters of } 1000 \text { GPs } \\
\text { that are yearly randomly selected. } \\
\text { Each encounter contains data on up } \\
\text { to } 4 \text { problems treated, drugs } \\
\text { prescribed, treatments conducted, }\end{array}$ & $\begin{array}{l}\text { April } \\
\text { 2002- } \\
\text { March } \\
2007 \text { from }\end{array}$ & $\begin{array}{l}\text { - Percentage of patients that } \\
\text { received a glycosylated haemoglobin } \\
\text { blood test during GP consult }\end{array}$ & $\begin{array}{l}\text { - PIP-DI increased probability of a } \\
\text { HbA1c test being ordered by } 20 \\
\text { percentage points. } \\
\text { - For patients from Aboriginal and } \\
\text { Torres Straight Islander background } \\
\text { the increase was more than } 35 \\
\text { percentage points. }\end{array}$ \\
\hline
\end{tabular}

referrals written and pathology).

$N=12187:$ 1. Treatment group 1: accredited practices that use IT for internet, prescribing and medical records; 2. Treatment group 2: practices that are accredited and do not use IT for internet, prescribing and medical records; 3 . Control group: practices that are not accredited and do not use IT, for internet, prescribing and medical records.

Practice Incentive Descriptive study based on semi Program Diabetes structured face-to-face interviews (22 Incentive (PIP-DI) GP practices) [37]

$2003 \quad \begin{aligned} & \text { Implementation of components of } \\ & \text { diabetes cycle of care }\end{aligned}$

- Financial incentives may promote better clinical management. GPs claiming incentives were more likely to comply with all requirements than GPs that did not claim incentives.

- External incentives and clinical IT were most strongly associated with CMP use on the basis of summary measure: $\mathrm{PO}$ care management index, extern incentives (bonus from health plans, public recognition, better contracts with health plans) quality reporting to outside organization (HEDIS data, clinical outcome data, results of quality improvement projects, patient satisfaction data), IT use
- Use of the most strongly associated incentives (public recognition and better contracts for healthcare quality) was associated with use of 1.3 and 0.7 additional CMPs (significant).

- Receiving a bonus for scoring well on quality of care measures was not significantly associated with CMP use. 


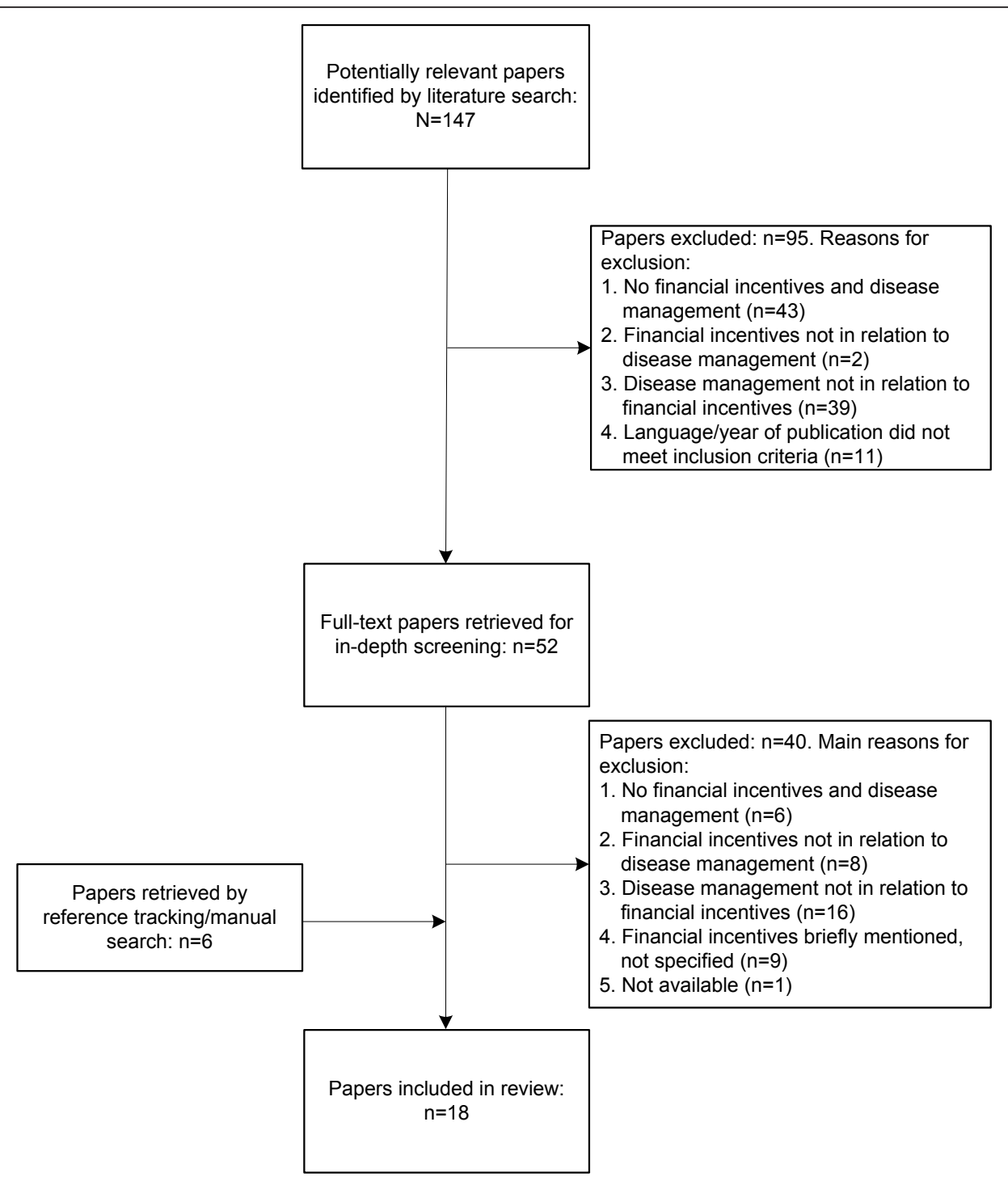

Figure 1 Flow chart of literature screening process.

disease management programs (further referred to as DMP-P4P) [34]. One P4P scheme was introduced in Australia: 8. Practice Incentive Program Diabetes Incentive (PIP-DI) [35-38].

We distinguished two categories of P4P schemes: 1. $\mathrm{P} 4 \mathrm{P}$ schemes in which financial incentives are granted to healthcare providers for delivering chronic care through disease management. In these schemes, rewards are granted by health insurers, health plans or managed care organizations if healthcare providers deliver chronic care via disease management programs (WNY-P4P, PBIP, BWPO-P4P, BTE, IHA-P4P, PIP-DI, and MPGPD) and 2. P4P schemes in which financial incentives are granted to health insurers to motivate them to enroll patients in disease management programs (DMP$\mathrm{P} 4 \mathrm{P})$. In this scheme sickness funds are rewarded by the
German government for enrolling patients in disease management programs.

\section{Elements of CCM}

Five of the eight included P4P schemes were part of a larger scheme of interventions (i.e. quality improvement program) to improve quality of chronic care (WNY-PIP, PBIP, BWPO-P4P, PIP-DI, and MPGPD). In these schemes, P4P was simultaneously implemented with other interventions that can be related to elements of the CCM. Financial incentives were directed at healthcare providers to reward their participation in these schemes of quality improvement interventions. Three of the eight included P4P schemes were solely implemented (BTE, IHA-P4P, and DMP-P4P). In these P4P schemes, financial incentives are directed at healthcare providers or health insurers to stimulate them to 
implement interventions that can be related to elements of the CCM. In these schemes, financial incentives are granted after the implementation of interventions related to elements of the CCM.

Irrespective of the type of P4P scheme (i.e. P4P schemes part of a larger scheme of interventions vs. sole P4P schemes), we determined that the schemes stimulated delivery of chronic care through disease management by interventions that can be related to the same CCM elements. Interventions related to the CCM elements "decision support" (e.g. clinical guidelines, assessment tools) and "adoption of a clinical information system” (e.g. electronic medical records, reminder letters, sharing practice specific data for benchmarking and reflective information feedback) were observed in almost all P4P schemes. Self-management support interventions (e.g. patient education) were observed in WNY-P4P, PIP-DI, MPGPD, and DMP-P4P, whereas delivery system design interventions (e.g. home visits, patient outreach coordinator) were only observed in the WNYP4P, MPGPD, and BWPO-P4P.

\section{Goals}

Generally, the goals of the P4P schemes were to stimulate delivery of high-quality and cost-effective chronic care, and ultimately to improve patient health. Most P4P schemes focused on delivery of integrated care for diabetes and/or asthma (WNY-P4P; BWPO-P4P; BTE; IHA; PIP-DI; MPGPD; DMP-P4P). Some P4P schemes additionally focused on care to other chronic patients including cardiac care (BTE; IHA-P4P; MPDGP), depression care (BTE), and COPD care (DMP-P4P), while of one $\mathrm{P} 4 \mathrm{P}$ scheme the targeted patient population was unknown (PBIP).

\section{Type}

In seven of the eight P4P schemes, financial incentives were framed as rewards for delivering chronic care through disease management (WNY-P4P; PBIP; BTE; IHA-P4P; PIP-DI; MPGPD) or for enrolling patients in disease management programs (DMP-P4P). In one P4P scheme (BWPO-P4P), the financial incentive was framed as a penalty. Annual physician or hospital fees were withheld and were only returned if quality targets were achieved.

\section{Incented entity}

The incented entities differed over the eight included $\mathrm{P} 4 \mathrm{P}$ schemes. In seven P4P schemes, financial incentives were granted to healthcare providers of which five were granted to groups of healthcare providers (e.g. physician groups, multidisciplinary groups of caregivers) (PBIP; BWPO-P4P; IHA-P4P; PIP-DI; MPGPD), whereas two were granted to individual healthcare providers (e.g. recognized physician, nurse practitioner, physician assistant) (WNY-P4P; BTE). In one P4P scheme, the financial incentive was granted to sickness funds (DMP-P4P).

\section{Focal quality behavior}

In most P4P schemes, financial incentives were granted on the basis of performance on a combination of structure $(n=6)$ and/or process indicators $(n=6)$. Performance on outcome indicators was less frequently used as a basis for granting financial incentives $(n=4)$. In one P4P scheme, the financial incentive was only based on performance on structure indicators (DMP-P4P). In two P4P schemes, financial incentives were based on performance on structure and process outcomes (BTE; PIP-DI). In three P4P schemes, financial incentives were based on performance on process and outcome indicators (WNY-PIP; BWPO-P4P; MPGPD) and in two P4P schemes, financial incentives were based on structure, process, and outcome indicators (PBIP; IHA-P4P).

Structure indicators were mostly based on the use of IT services (e.g. patient registries, recall/reminder system, electronic medical records) (e.g. BTE; PIP-DI) or having implemented a certified program (DMP-P4P). Process measures targeted at clinical quality (e.g. working according to national standards of clinical care management, patient education and support) and were often a subset of the Health Plan Employer Data and Information Set (HEDIS) (e.g. BWPO-P4P; BTE; IHA-P4P; MPGPD). Of the four financial incentives that were (partly) granted on the basis of performance on outcome measures, two P4P schemes targeted at patient experience/satisfaction (PBIP; IHA-P4P) whereas three financial incentives (WNY-P4P; BWPO-P4P, MPGPD) targeted at clinical outcome (i.e. $\%$ of patients with HbA1c value $\leq 7.5$ or blood pressure $\leq 130 / 80$ ).

\section{Scope}

Selective incentives were observed in six P4P schemes (WNY-P4P; BWPO-P4P; BTE; IHA-P4P; PIP-DI; MPGPD). These incentives targeted at specific domains of quality (e.g. periodic blood pressure readings, cholesterol screening, HbA1c screening) and were granted on the basis of scoring on established criteria of quality performance. A general incentive was observed in one P4P scheme (DMP-P4P). This incentive targeted at a general domain of quality, i.e. whether or not sickness funds set up disease management programs. The scope of one P4P scheme was unknown (PBIP).

\section{Motivation}

Information about whether the P4P-schemes affect intrinsic or extrinsic motivation to deliver high quality care was lacking in the papers that we included in our review. We therefore can not provide any information about this characteristic of the included P4P schemes.

\section{Scale}

Absolute performance incentives were observed in six P4P schemes (WNY-P4P; BTE; IHA; PIP-DI; DMP-P4P; MPGPD). Incentives were granted if healthcare providers or sickness funds meet established performance 
measures. Relative performance incentives were observed in three P4P schemes (PBIP; PIP-DI; MPGPD). Healthcare providers participating in these programs only received bonus payment if they exceeded performance of other healthcare providers.

\section{Certainty}

Five of the P4P schemes (WNY-PIP; BTE; IHA-P4P; PIP-DI; DMP-P4P) had guaranteed reward schedules, provided that established targets were achieved. Two studies illustrate by the number of physicians not receiving a reward that, despite the (partly) guaranteed reward schedules, targets established in the P4P schemes may not be easily achievable. A study evaluating the WNYPIP showed that 13 out of 21 physicians earned a financial reward [16]. Also a study that evaluated the MPGPD, a scheme where rewards are granted on the basis of absolute and relative performance, showed that 2 out of 10 physician groups earned a financial reward [32].

In three P4P schemes (PBIP; BWPO-P4P; MPGPD), providing financial incentives was (partly) based on high relative performance. Rewarding only the top performers creates competition. This approach introduces uncertainty because a bonus depends not only on a healthcare providers' own performance but also on that of other healthcare providers in the network. Healthcare providers don't know in advance whether they will exceed competing healthcare providers.

\section{Size, frequency, and duration}

Of most P4P schemes, size, frequency, and duration of the financial incentives were not or only briefly described. Of six P4P schemes (WNY-PIP; PIP-DI; BWPO-P4P; BTE, IHA-P4P; MPGPD) some information was available about the incentive size. Of four of these incentives, the size depended on the composite performance score (WNY-P4P; BWPO-P4P; BTE; MPGPD). The precise size of rewards could change over time and could differ between the health plans that participated in the quality improvement programs. Health plans that participated in the IHA-P4P scheme determined their own budget and methodology for calculating and distributing payments to physician groups (IHA-P4P). Healthcare providers participating in PIP-DI received payment per standardized whole patient equivalent (IT structure) or per patient (that completed a cycle of care). No information was available about the size of the financial incentives granted via the PBIP and DMP-P4P.

\section{Effects pay-for-performance schemes}

Of the 18 included papers, only five reported effects of P4P on healthcare quality [16,30,37-39], whereas no papers were found that reported the effects of $\mathrm{P} 4 \mathrm{P}$ on healthcare costs. Of the five papers, four reported the effects of specified P4P schemes (WNY-PIP; PIP-DI;
IHA-P4P) on healthcare performance, whereas one paper reported the effects of financial incentives in general versus the effects of other external incentives.

The evaluated aspects of healthcare delivery differed over the studies. The studies showed positive effects of P4P on the quality of care delivered. Scott et al. [38] revealed that PIP-DI increased the probability of a HbA1c test being ordered which implies a positive effect on quality of care in diabetes management. In the other study on PIP-DI, physicians were asked to what extent they implemented the nationally established minimum requirements to diabetes care. The study indicates that financial incentives promote better clinical management of diabetes patients: GPs claiming financial incentives were more likely to comply with all requirements than GPs that did not claim incentives [37]. Also the study that evaluated the effects of WNY-PIP on healthcare quality showed that the majority of the participating physicians improved their average score on process (i.e. screening of clinical parameters) and outcome (i.e. patient outcome) indicators [16]. The study evaluating the effects of IHA-P4P found that quality improvement efforts, such as P4P schemes, are positively related with improved delivery of clinical processes of care.

The study that evaluated the effects of external incentives, including financial incentives, did not find a significant relationship between receiving a financial reward for scoring well on quality of care measures between organized care management processes. However, significant relationships were found for other external incentives such as public recognition and better contracts for healthcare quality and organized care management processes [39].

\section{Discussion}

This systematic literature review presents an overview of P4P schemes that are currently used to stimulate delivery of chronic care through disease management and provides insights into their effects. P4P schemes are increasingly implemented in the healthcare system to encourage improvements in healthcare quality. Wellknown examples of such schemes are the Hospital Quality Incentive Demonstration Project introduced in the USA and the NHS Quality and Outcomes Framework and the Commissioning for Quality and Innovation Payment Framework introduced in the UK [12,21,40,41]. The increasing number of implemented P4P schemes has led to a mounting number of studies on the effects of such schemes. These studies have, however, not specified their results for P4P schemes that are used to stimulate delivery of chronic care through disease management [42-44]. The increasing number of disease management programs that have been implemented over the last years, has urged the need for insight into 
P4P schemes focusing on the implementation of disease management programs.

The included P4P schemes were systematically disentangled according to the dimensions of P4P schemes defined by Conrad and Perry [10]. This classification is in line with the characterization of P4P schemes of other authors who have recently published their work in this field [e.g. 12, 43, 45]. Systematically describing the P4P schemes facilitated comparison of their characteristics and effects. This process revealed that retrieving complete and up-to-date information about the characteristics of P4P schemes was difficult. In most papers schemes were not well-described and information given was often dated. Particularly, information about the certainty, motivation, size, frequency, and duration of the P4P schemes was difficult to obtain.

The included P4P schemes were rather similar in their goals (i.e. improving quality, continuity, and efficiency of care for the chronically ill) but differed in how to achieve these goals. Financial incentives targeting at healthcare providers strived for improvement of quality and continuity of care by stimulating healthcare providers to deliver chronic care through disease management, whereas incentives targeting at health insurers strived for improvement of quality and continuity of care by stimulating health insurers to enroll patients in disease management programs. We did not identify P4P schemes in combination with financial incentives for patients (e.g. rewarding patients for participating in disease management programs).

The included P4P schemes mostly stimulated delivery of chronic care through disease management by interventions that can be related to the CCM elements "decision support" and "clinical information system". This finding can possibly be explained by the fact that interventions related to these CCM elements are mostly implemented before interventions related to the other elements of the CCM $[13,14]$.

Our literature review yielded only five papers that reported studies on the effects of P4P on healthcare quality [16,30,37-39]. No papers were found that reported studies evaluating the effects of $\mathrm{P} 4 \mathrm{P}$ on healthcare costs. Most studies showed positive effects of P4P on the quality of care delivered. It should, however, be noted that the observed differences between schemes hinders comparability of their effects on healthcare quality and as a consequence drawing conclusions on the effectiveness of P4P to stimulate delivery of chronic care through disease management in general. It is therefore not possible to determine the characteristics of P4P schemes that may contribute to improved healthcare quality. This is in line with earlier studies that suggest that the effectiveness of P4P schemes is highly variable in terms of e.g. complications, ER waiting times, length of hospital stay, and screening rates and that the effectiveness depends on the design of the schemes and the characteristics of the context where they are introduced $[11,43,44]$. It should further be noted, that since our study mainly yielded studies showing positive effects of P4P schemes, publication bias should be taken into account. Since almost no studies were found showing no effects of $\mathrm{P} 4 \mathrm{P}$, it is difficult to determine the characteristics of P4P schemes that may not affect healthcare quality and healthcare costs.

Another issue which complicates drawing conclusions with regard to the effectiveness of $\mathrm{P} 4 \mathrm{P}$, which is also highlighted by other authors, is that P4P schemes are often not solely implemented [i.e. 19, 44]. Also the $\mathrm{P} 4 \mathrm{P}$ schemes included in this study were mostly part of a larger scheme of interventions and were simultaneously implemented with other interventions than can be related to elements of the CCM such as patient registries, physician reminders and feedback, and the implementation of evidence-based guidelines and protocols. Such interventions also focus on changing healthcare providers' behavior and may interact with the potential effect of P4P. It is therefore difficult to determine the isolated effect of P4P on healthcare quality and related costs. Additionally, as also mentioned by Chaix-Couturier et al. [11] and Christianson et al. [44], contextual factors like the characteristics of the healthcare system where the P4P scheme is implemented (e.g. healthcare purchasing system, degree of regulation, financing mechanisms of the healthcare system), organizational aspects of the healthcare organization where the P4P scheme is implemented, and personal characteristics of the healthcare providers participating in the P4P scheme may also interact with the effect of the scheme and therefore further complicates comparability of the effects of P4P schemes. Hence, to interpret the results of the included studies it is also relevant to have information about the healthcare system where the P4P scheme is implemented and the simultaneously implemented interventions and their features.

Although the aforementioned issues complicate drawing conclusions with regard to which $\mathrm{P} 4 \mathrm{P}$ schemes are most successful, there are some indications for the design characteristics of P4P schemes that may produce the largest effects. First, payment on the basis of scoring on process-based incentives may be more effective than indicators that are less directly related to a healthcare providers' performance $[10,43]$. Second, P4P schemes including a blend of individual- and group-level incentives may be more effective than P4P schemes only including individual or only including group-level incentives. Some performance issues can be improved most efficiently through group action, whereas others can be 
improved most efficiently through individual action $[10,43,45]$. Third, there are indications that P4P schemes rewarding absolute performance may be more effective than schemes rewarding relative performance. Rewarding relative performance may create uncertainty about the amount of additional revenue that can be obtained, because one's reward depends on the performance of other healthcare providers in the network. This, in turn, may result into unwillingness of providers to make investments in quality improvement. Moreover, only rewarding top performers may discourage healthcare providers with lower baseline quality to improve their services since for them it is difficult to outperform healthcare providers who already have high baseline quality $[10,21,43,45]$. It should, however, be noted that there are also indications that relative performance incentives are more effective in improving healthcare quality since they offer an ongoing incentive for initial high-quality providers to continue to perform well relative to their network [21].

On the basis of the current literature it is unclear whether these findings also apply to the design of $\mathrm{P} 4 \mathrm{P}$ schemes to encourage delivery of care through disease management. Since evidence for the effectiveness of these P4P schemes is scarce, it is recommended to design methodologically sound studies to gain insight into the design characteristics that are most successful. Empirical evidence is necessary to carefully design P4P schemes and to ensure their effectiveness $[10,42,43,45]$. It is further recommended to determine the effect of P4P on equity in healthcare. A recent study of Doran et al. [46] suggests that the Quality and Outcomes Framework, implemented in the United Kingdom, has the potential to reduce inequalities in the delivery of primary clinical care. It is unknown if P4P schemes used to stimulate delivery of chronic care through disease management will produce similar effects. It is therefore recommended to include equity in healthcare as an outcome in future studies in this field.

When designing P4P schemes to stimulate disease management, it should further be taken into account that P4P schemes may also have negative consequences for the quality of care. A potential negative effect, also known as the "distortion effect", is the theoretical concern that stimulation of efforts on the measures of healthcare performance included in the P4P scheme may discourage efforts on aspects of healthcare performance that are not included and rewarded by the scheme. As a result, P4P may result into reduced healthcare quality, rather than into the intended improved healthcare quality [16,32]. Such potential side-effects of P4P should be included in future studies evaluating the effectiveness of P4P schemes.

\section{Conclusion}

The number of P4P schemes intending to encourage delivery of chronic care through disease management is still limited. Hardly any information is available about the effects of such schemes on healthcare quality and healthcare costs.

\section{Acknowledgements}

The authors gratefully acknowledge the involvement of Luqman Tariq at the start of our study. The authors also thank Richard Heijink for his comments on an earlier version of the manuscript.

\section{Authors' contributions}

$\mathrm{SdB}$ and JS performed the literature search and selected relevant papers for the review. All authors analyzed the included papers. SdB drafted the manuscript and JS and CB revised the manuscript. All authors read and approved the final manuscript.

\section{Competing interests}

The authors declare that they have no competing interests.

Received: 2 March 2011 Accepted: 14 October 2011

Published: 14 October 2011

\section{References}

1. World Health Organization: The global burden of disease, 2004 update. [http://www.who.int/healthinfo/global_burden_disease/ GBD_report_2004update_full.pdf], Retrieved 21 December 2009 from.

2. Marengoni A, Winblad B, Karp A, Fratiglioni L: Prevalence of chronic diseases and multimorbidity among the elderly population in Sweden. American Journal of Public Health 2008, 98(7):1198-1200.

3. World Health Organization: Preventing chronic diseases: a vital investment.[http://whqlibdoc.who.int/publications/2005/9241563001_eng. pdf], Retrieved 21 December 2009 from.

4. Greß S, Baan CA, Clanan M, Dedeu T, Groenewegen P, Howson H, Maroy L, Nolte E, Redaèlli M, Saarelma O, et al: Co-ordination and management of chronic conditions in Europe: The role of primary care - Position paper of the European forum for primary care. Quality in Primary Care 2009, 17(1):75-86.

5. Wagner EH, Bennett SM, Austin BT, Greene SM, Schaefer JK, Vonkorff M: Finding common ground: patient-centeredness and evidence-based chronic illness care. Journal of Alternative and Complementary Medicine 2005, 11(Suppl 1):S7-15.

6. Mattke S, Seid M, Ma S: Evidence for the effect of disease management: is $\$ 1$ billion a year a good investment? American Journal of Managed Care 2007, 13(12):670-676.

7. Wagner EH, Austin BT, Davis C, Hindmarsh M, Schaefer J, Bonomi A: Improving chronic illness care: translating evidence into action. Health Affairs (Millwood) 2001, 20(6):64-78.

8. Singh D: How can chronic disease management programmes operate across care settings and providers? Birmingham: World Health Organization; 2008.

9. De Bruin SR, Heijink R, Lemmens L, Struijs JN, Baan CA: Impact of disease management programs on healthcare expenditures for patients with diabetes, depression, heart failure or chronic obstructive pulmonary disease: a systematic review of the literature. Health Policy 2011, 101(2):105-121.

10. Conrad DA, Perry L: Quality-based financial incentives in health care: can we improve quality by paying for it? Annual Review of Public Health 2009, 30:357-371.

11. Chaix-Couturier C, Durand-Zaleski I, Jolly D, Durieux P: Effects of financial incentives on medical practice: results from a systematic review of the literature and methodological issues. International Journal for Quality in Health Care 2000, 12(2):133-142.

12. Rosenthal MB, Fernandopulle R, Song HR, Landon B: Paying for quality: providers' incentives for quality improvement. Health Affairs (Millwood) 2004, 23(2):127-141. 
13. Drewes H, Vrijhoef B, Elissen A, Lemmens K, Lemmens L, Meeuwissen J, Steuten LM, Meijboom B, Westert G, Baan CA: Chronic care management: how to best deal with the variation in its effectiveness?, (submitted).

14. Lemmens K Lemmens L, Boom J, Drewes H, Meeuwissen J, Steuten L, Vrijhoef H, Baan CA: Chronic care management for patients with COPD: A critical review of available evidence., Accepted for publication by Journal of Evaluation in Clinical Practice.

15. Wagner $\mathrm{EH}$ : The role of patient care teams in chronic disease management. British Medical Journal 2000, 320(7234):569-572.

16. Beaulieu ND, Horrigan DR: Putting smart money to work for quality improvement. Health Services Research 2005, 40(5 Pt 1):1318-1334

17. BlueCross BlueShield Association: The Performance Based Incentive Program (PBIP): A Model for Quality Improvement and Cost.[http://www. bcbs.com/innovations/], Retrieved 28 February 2011 from.

18. Levin-Scherz J, DeVita N, Timbie J: Impact of pay-for-performance contracts and network registry on diabetes and asthma HEDIS measures in an integrated delivery network. Medical Care Research and Review 2006, 63(1 Suppl):14S-28S.

19. Smith AL: Merging P4P and disease management: how do you know which one is working? Journal of Managed Care Pharmacy 2007, 13(2 Suppl B):S7-10.

20. Ahmann AJ: Guidelines and performance measures for diabetes. American Journal of Managed Care 2007, 13 Suppl 2:S41-46.

21. Bonis PA: Quality incentive payment systems: promise and problems. Journal of Clinical Gastroenterology 2005, 39(4 Suppl 2):S176-182.

22. Health Care Incentives Improvement Institute: Bridges to Excellence.[http:// www.bridgestoexcellence.org/], Retrieved 28 February 2011 from.

23. Anonymous: Aligning incentives in bridges to excellence. Managed Care Interface 2004, Suppl: 5-6, 13.

24. Anonymous: CA health plans collaborate in 'pay for performance' program to boost chronic care management. Disease Management Advisor 2002, 8(4):54-58, 49

25. Berenbeim D: The medical group pay-for-performance initiative in California and diabetes care. Managed Care Interface 2003, Suppl C:3-4

26. Cutler TW, Palmieri J, Khalsa M, Stebbins M: Evaluation of the relationship between a chronic disease care management program and California pay-for-performance diabetes care cholesterol measures in one medical group. Journal of Managed Care Pharmacy 2007, 13(7):578-588.

27. Integrated Healthcare Association: Integrated Healthcare Association (IHA), Pay for Performance (P4P) Program. Overview.[http://www.iha.org/ pdfs_documents/p4p_california/P4PFactSheet_July2010.pdf], Retrieved 28 February 2011 from

28. Integrated Healthcare Association: Integrated Healthcare Association Pay for Performance (P4P) Program, Program Results.[http://www.iha.org/ program_results.html], Retrieved 28 February 2011 from.

29. Integrated Healthcare Association: Integrated Healthcare Association Pay for Performance (P4P) Program, Awards.[http://www.iha.org/p4p_awards. html], Retrieved 28 February 2011 from.

30. Damberg CL, Shortell SM, Raube K, Gillies RR, Rittenhouse D, McCurdy RK, Casalino LP, Adams J: Relationship between quality improvement processes and clinical performance. American Journal of Managed Care 2010, 16(8):601-606

31. Damberg CL, Raube K, Williams T, Shortell SM: Paying for performance: implementing a statewide project in California. Quality Management in Health Care 2005, 14(2):66-79.

32. Kautter J, Pope GC, Trisolini M, Grund S: Medicare physician group practice demonstration design: quality and efficiency pay-forperformance. Health Care Financing Review 2007, 29(1):15-29.

33. Trisolini M, Aggarwal J, Leung M, Pope GC, Kautter J: The Medicare Physician Group Practice Demonstration: lessons learned on improving quality and efficiency in healthcare. The Commonwealth Fund; 2008

34. Gre $\beta$ S, Focke A, Hessel F, Wasem J: Financial incentives for disease management programmes and integrated care in German social health insurance. Health Policy 2006, 78(2-3):295-305.

35. Australian Government. Medicare Australia: Practice Incentives Program (PIP) payments and calculations.[http://www.medicareaustralia.gov.au/ provider/incentives/pip/payment-formula/index.jsp], Retrieved 28 February 2011 from.

36. Australian Government. Medicare Australia: Practice Incentives Program (PIP).[http://www.medicareaustralia.gov.au/provider/incentives/pip/index.jsp], Retrieved 28 February 2011 from.
37. Saunders M, Schattner $P$, Mathews M: Diabetes 'cycles of care' in general practice - do government incentives help? Australian Family Physician 2008, 37(9):781-784

38. Scott A, Schurer S, Jensen PH, Sivey P: The effects of an incentive program on quality of care in diabetes management. Health Economics 2009, 18(9):1091-1108.

39. Casalino L, Gillies RR, Shortell SM, Schmittdiel JA, Bodenheimer T, Robinson JC, Rundall T, Oswald N, Schauffler H, Wang MC: External incentives, information technology, and organized processes to improve health care quality for patients with chronic diseases. JAMA 2003, 289(4):434-441.

40. Maynard A, Bloor K: Will financial incentives and penalties improve hospital care? British Medical Journal 2010, 340:c88.

41. Serumaga B, Ross-Degnan D, Avery AJ, Elliott RA, Majumdar SR, Zhang F Soumerai SB: Effect of pay for performance on the management and outcomes of hypertension in the United Kingdom: interrupted time series study. British Medical Journal 2011, 342:d108.

42. Rosenthal MB, Frank RG, Li Z, Epstein AM: Early experience with pay-forperformance: from concept to practice. JAMA 2005, 294(14):1788-1793.

43. Van Herck P, De Smedt D, Annemans L, Remmen R, Rosenthal MB, Sermeus W: Systematic review: Effects, design choices, and context of pay-for-performance in health care. BMC Health Services Research 2010, 10:247.

44. Christianson J, Leatherman S, Sutherland K: Lessons from evaluations of purchaser pay-for-performance programs. Medical Care Research and Review 2008, 65(6):5S-35S.

45. Rosenthal MB, Dudley RA: Pay-for-performance. Will the latest payment trend improve care? JAMA 2007, 297(7):740-743.

46. Doran T, Fullwood C, Kontopantelis E, Reeves D: Effect of financial incentives on inequalities in the delivery of primary clinical care in England: analysis of clinical activity indicators for the quality and outcomes framework. Lancet 2008, 372(9640):728-736.

\section{Pre-publication history}

The pre-publication history for this paper can be accessed here: http://www.biomedcentral.com/1472-6963/11/272/prepub

\section{doi:10.1186/1472-6963-11-272}

Cite this article as: de Bruin et al:: Pay-for-performance in disease management: a systematic review of the literature. BMC Health Services Research 2011 11:272.

\section{Submit your next manuscript to BioMed Central and take full advantage of:}

- Convenient online submission

- Thorough peer review

- No space constraints or color figure charges

- Immediate publication on acceptance

- Inclusion in PubMed, CAS, Scopus and Google Scholar

- Research which is freely available for redistribution

Submit your manuscript at www.biomedcentral.com/submit
C Biomed Central 